\title{
Application of GIS Tools to Describe the Location of New Registered Parcels
}

\begin{abstract}
The article presents the possibility of using GIS (Geographic Information System) in the scope of the elaboration of calls for participants in land consolidation (LC). It shows the tools and the way they are used, as well as the possibility of automating this process.

In the process of land consolidation and exchange, when the LC project is developed, calls for LC participants are prepared. Usually these documents are done manually by referring to the nearest plots of state before LC. The information given in the notification is, among others, the distance and direction in which the new plot is located away from the nearest plot of the old state.

Using the GIS system, a tool has been developed that automatically shows information about the designation, direction and distance of parcel nearest to the input parcels and indicates selected nearest parcels on the map. The results were checked, and the tools used were assessed for their suitability for this type of task.

In conclusion, specifying the distance and direction alone, especially at large distances, may be not accurate enough. However, the ability to automatically indicate the nearest plots before LC in relation to the newly designed plot is extremely valuable and significantly accelerates LC work.
\end{abstract}

Keywords: finding nearest feature, land consolidation, GIS

Received: 30 July 2019; accepted: 28 November 2019

(C) 2020 Author. This is an open access publication, which can be used, distributed and reproduced in any medium according to the Creative Commons CC-BY 4.0 License.

1 AGH University of Science and Technology, Department of Integrated Geodesy and Cartography, Krakow, Poland, email: basista@agh.edu.pl

ORCID ID: https://orcid.org/0000-0002-0820-5380 


\section{Introduction}

Many people take part in the process of land consolidation and exchange (LC), both on the part of project contractors and participants. Good communication is the basis for the success of this task. When an LC project is finished, calls for participants are prepared, in which they are called to land, in order to show a new plot location [1]. This is usually done manually by referring to the nearest state plots before merging. Information that is given in this notification is, among others, the distance and direction in which a new plot is removed from the nearest to it plot of the old state. The notification should also indicate the specific place and time of the meeting.

The geoportal with a merge project could be a good solution here $[2,3]$. Thanks to it, it would be easy to identify the location of new plots. It is certainly less labor-intensive than both the manual method and the one presented in this work, but it is difficult for reception, for example by the elderly. Therefore, calls are still being developed in a traditional way.

The analysis of works on this subject show many examples of the use of GIS systems in the field of LC, especially in the development of the graphic part of the assumptions for the LC project. They are also used in analyzes aimed at identifying areas requiring consolidation [4], for example, analyzing the availability of plots for public roads [5], analysis of environmental properties of the area subjected to consolidation works, for example in terms of soil erosion [6]. The use of GIS tools in the development of a consolidation project in engineering works [7] is hardly ever presented.

The article presents the possibility of using GIS (Geographic Information System) in the scope of the elaboration of calls for participants in land consolidation. It shows the tools and the manner in which they are used, as well as the possibility of automating this process.

The research was carried out on the Nieciecza LC object, which consists of Nieciecza village (424 ha), Czyżów village (200 ha), Podlesie Dębowe village (17 ha) and Żabno town (4.5 ha) located in the Żabno commune, Tarnów county, Małopolska voivodship. In this object, 932 registered plots were designed. The state before the merger consisted of 1,518 plots. The expected finish date for the consolidation works is 2020 .

\section{Methodology}

The input data were two layers of plots in the pre-and post-merger state - polygonal type objects, the shapefile format, with descriptive information about the plot number, register unit and the number of the Participant's LC Card (KUS).

First, a proximity table was generated, where the input objects were objects on the parcel layer after merge, and nearest objects were objects on the parcel layer 
before merge. Parameters are set to allow the distances to all plots to be computed before consolidation for each parcel after consolidation. The table of proximity contains information about the distance between the input and nearest objects. The distance in the case of polygonal objects is determined between the nearest nodes of these objects (Fig. 1).

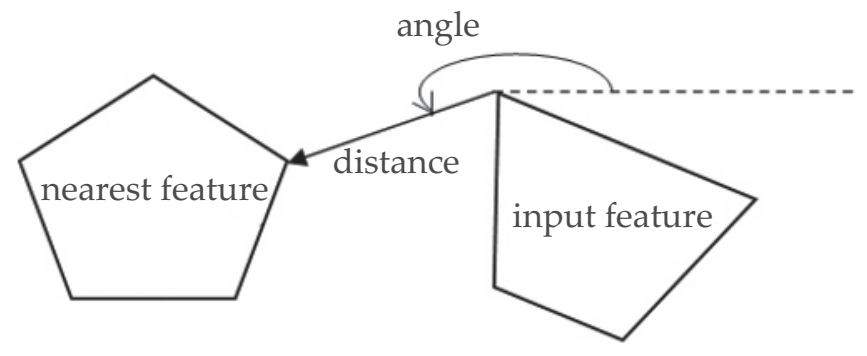

Fig. 1. The method of calculating distance and angle between polygon objects

Additionally, information about the angle is given in the proximity table, which is determined at the node point of the input object and is measured from the horizontal $\mathrm{X}$ axis to the direction of the line connecting the input object with the nearest object. On the left (up) from the $\mathrm{X}$ axis the angle takes values from $0^{\circ}$ to $180^{\circ}$, on the right (down) from $0^{\circ}$ to $-180^{\circ}$.

The proximity table also contains the identifier of the input object (IN_FID) and the identifier of the nearest object (NEAR_FID), matching ranking (NEAR_RANK), where the lower the number, the closer the object and the coordinates of the points between which the distance is determined (FROM_XY, NEAR_XY) (Fig. 2).

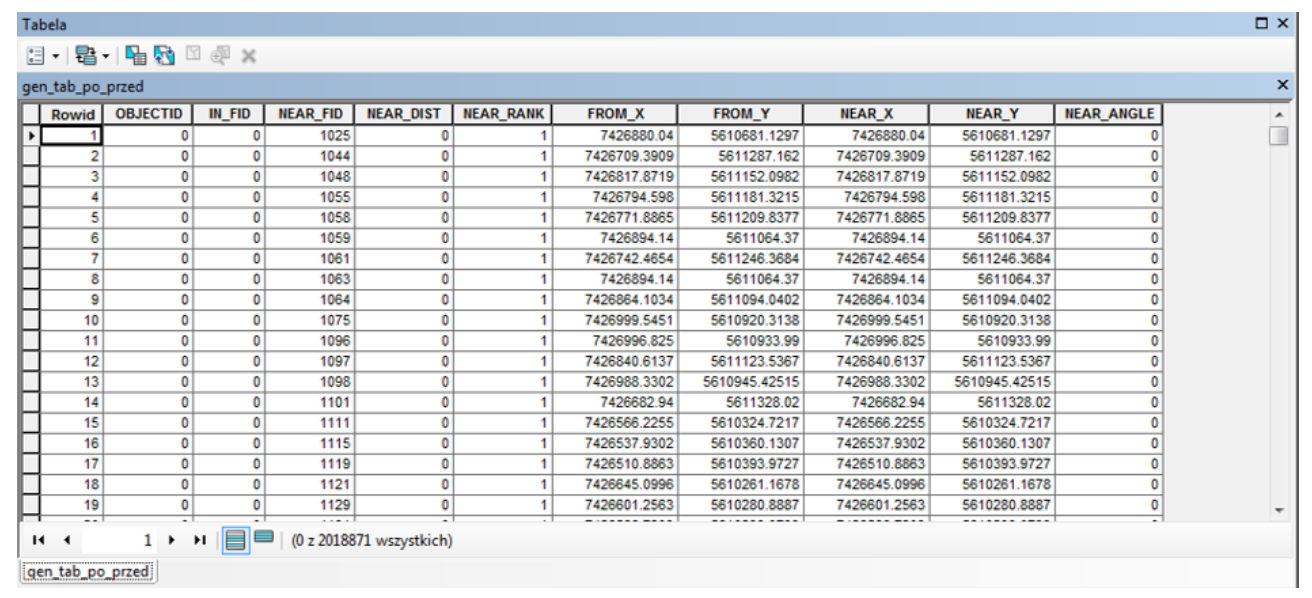

Fig. 2. Presentation of the proximity table 
In the next step, associating the parcel layer identifiers before and after merging with the corresponding identifiers in the proximity table was necessary, by joining the proximity table by the IN_FID with FID keys after merging and NEAR_ID with FID keys from the parcels before merging. Thanks to this combination, the objects of the same LC participant (KUS) were selected.

Next, plots were selected which have the nearest parcels after consolidation, i.e. with the lowest value of the NEAR_RANK attribute. In a situation where there was more than one nearby plot, the first random one was chosen.

It is still necessary to convert the directional angle to the appropriate direction of the world sides, taking into account that the given angle is measured from the vertex of the plot after merging, and the opposite direction is needed. In case the distance and angle were 0 , the information "on the plot" was entered.

The resulting table contains the numbers of all parcels after merging together with the information assigned to them about the number of plot nearest to it, before the consolidation, the distance between these plots (given in meters) and the direction in which the parcel is located after merging in relation to the plot before consolidation. In order to add spatial information to the created table, it was merged with the layer of plots after consolidation identifying objects by the plot number. Thanks to this combination, the parcel layer after consolidation will contain direction and distance information in the attribute table (Fig. 3).

\begin{tabular}{|c|c|c|c|c|c|c|c|c|c|c|c|c|c|c|}
\hline \multicolumn{14}{|c|}{ Tabela } & \multirow[t]{2}{*}{$\square \times$} \\
\hline & - & 3.19 & 80 & $x$ & & & & & & & & & & \\
\hline \multicolumn{14}{|c|}{ parcels after $L C$} & $x$ \\
\hline & FID & Shape & No_after & No_before & KUS & DISTANCE & DIRECT & FROM_X & FROM_Y & NEAR_X & MEAR_Y & Shape_Leng & Shape_Area & A \\
\hline \multirow[t]{11}{*}{, } & 7 & Poligon & $483 / 2$ & $1 \_29 / 1$ & 483 & 912 & & 7489868.75 & 5556988.69 & 7489005.11 & 5556696.47 & 247.665032 & 2306.16645 & T \\
\hline & 52 & Poligon & $5001 / 41$ & 12 1126 & 5001 & 12 & & 7490544.57 & 5558405.76 & 7490533.36 & 5558401.32 & 1018.067711 & 3610.4969 & \\
\hline & 55 & Poligon & $5001 / 44$ & $12 \_106$ & 5001 & 1 & $E$ & $\begin{array}{l}7488680.7 \\
\end{array}$ & 5558288.86 & 7488679.38275 & 5558288.64546 & 577.349188 & 1420.05375 & \\
\hline & 96 & Poligon & $5029 / 1$ & 12 - 925 & 5029 & 412 & $E$ & 7489897.03 & 5556334.96 & 7489495.55 & 5556425.53 & 312.615505 & 5400.0922 & \\
\hline & 109 & Poligon & $5036 / 2$ & $12 \_1080$ & 5036 & 249 & $E$ & 7489505.48 & 5556534.63 & 7489266.43 & 5556604.04 & 338.333064 & 6387.47915 & \\
\hline & 138 & Poligon & $5062 / 3$ & 12_906 & 5062 & 19 & $\varepsilon$ & 7489428.4 & 5556755.87 & 7489409.85 & 5556753.73 & 392.245626 & 9321.0875 & \\
\hline & 258 & Poligon & $5151 / 2$ & $12-71$ & 5151 & 35 & $E$ & 7488610.24243 & 5557248.70203 & 7488578.53 & 5557234.3 & 292.374065 & 4996.0578 & \\
\hline & 367 & Poligon & $5234 / 1$ & $12 \_770 / 1$ & 5234 & 340 & $E$ & 7490089.31 & 5556538.26 & 7489779.11 & 5556677.64 & 126.727453 & 951.36795 & \\
\hline & 511 & Poligon & $5360 / 2$ & $12-91 / 3$ & 5360 & 247 & $\varepsilon$ & 7488771.09 & 5558079.85 & 7488542.95 & 5558174.25 & 768.151521 & 11742.3887 & \\
\hline & 563 & Poligon & $5598 / 1$ & 12 -92 & 5598 & 300 & & 7488855.12 & 5558242.25 & 7488555.18 & 5558229.29 & 399.823454 & 5336.9859 & \\
\hline & 576 & Poligon & $5604 / 4$ & $12 \_74$ & 5604 & 87 & & 7488613.1 & 5557371.11 & 7488532.62254 & 5557338.20205 & 505.963332 & 9875.5267 & - \\
\hline & 1 & & $1, \|$ & $\ddot{\mid}_{(0}$ z 932 & wszystk & kich) & & & & & & & & \\
\hline \multicolumn{15}{|c|}{ [parcels after $[C]$ ] } \\
\hline
\end{tabular}

Fig. 3. Presentation of the result table connected to the parcel layer after consolidation

Due to the numerous tools that had to be used to develop descriptions of the location of new plots, a model was created. The model automates the entire process and can be used to prepare notifications of participants of subsequent consolidation objects. In addition, this model shows the sequence of activities performed (Fig. 4). 


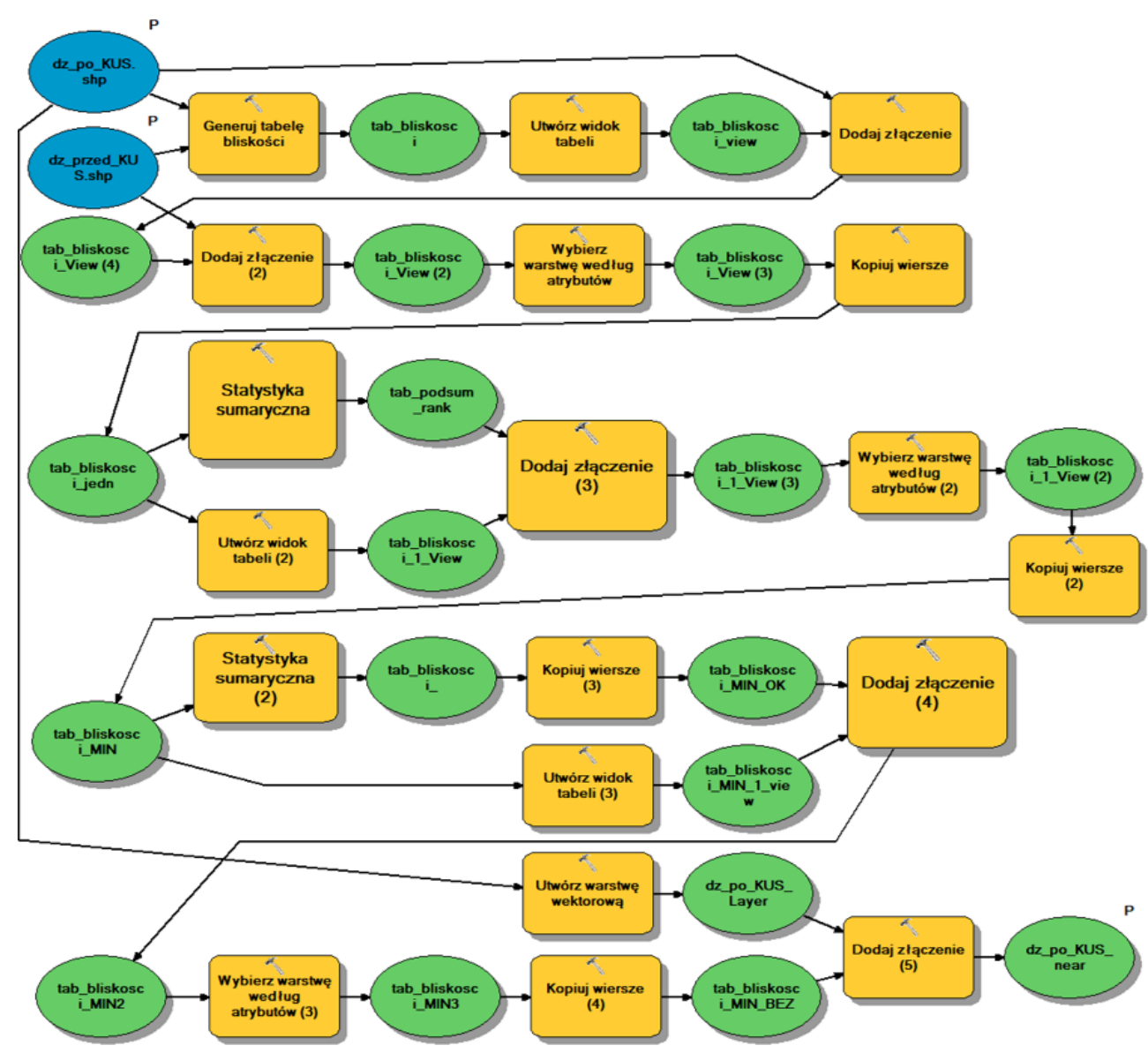

Fig. 4. Presentation of the model in the ModelBuilder ArcGIS application

\section{Results and Discussion}

The developed model was used to search for the nearest parcels for the Nieciecza LC object. The parcel layer after consolidation contained 932 registered plots. For each of these plots, information was generated about the nearest to it plot before the consolidation and the distance and direction in which it is located in relation to the plot before the consolidation. The user, pointing to the selected plot on the map after consolidation, receives descriptive information in the form of a number, distance and direction to the nearest plot of land. To point the nearest location on the map, it is necessary to link (one-to-many relation) layer with the parcels after consolidation with the parcel layer before consolidation (1,518 plots). In this way, the user will receive full information, both descriptive and spatial, about the location of the selected objects (Fig. 5). 


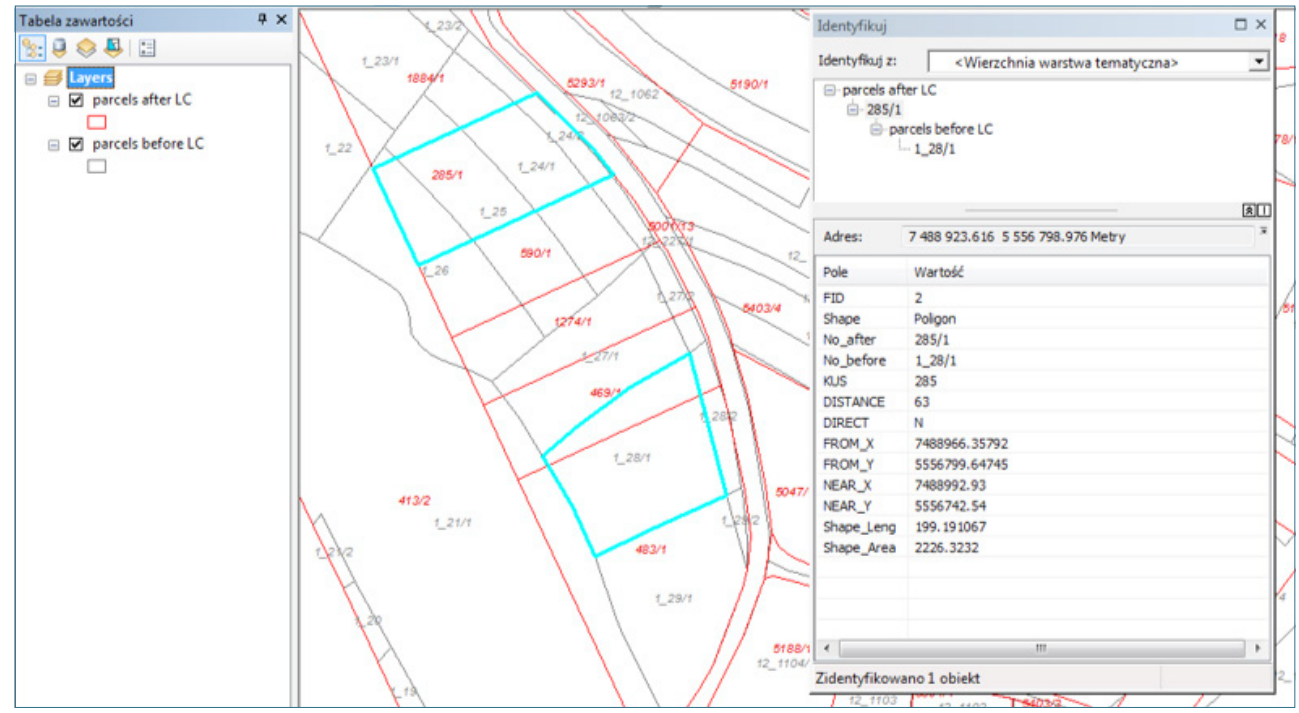

Fig. 5. Presentation of the identification of the nearest plot (1_28 / 1) to a given plot after consolidation (285/1)

The obtained results were checked. In order to check the calculated values, the vertices of the polygons on the basis of which the distances and angles were determined were marked (Fig. 6). In each case, the selection of nearest plots and calculated values were correct. In the case where the nearest plot coincided or was in contact with the plot before consolidation, the results did not raise any objections.

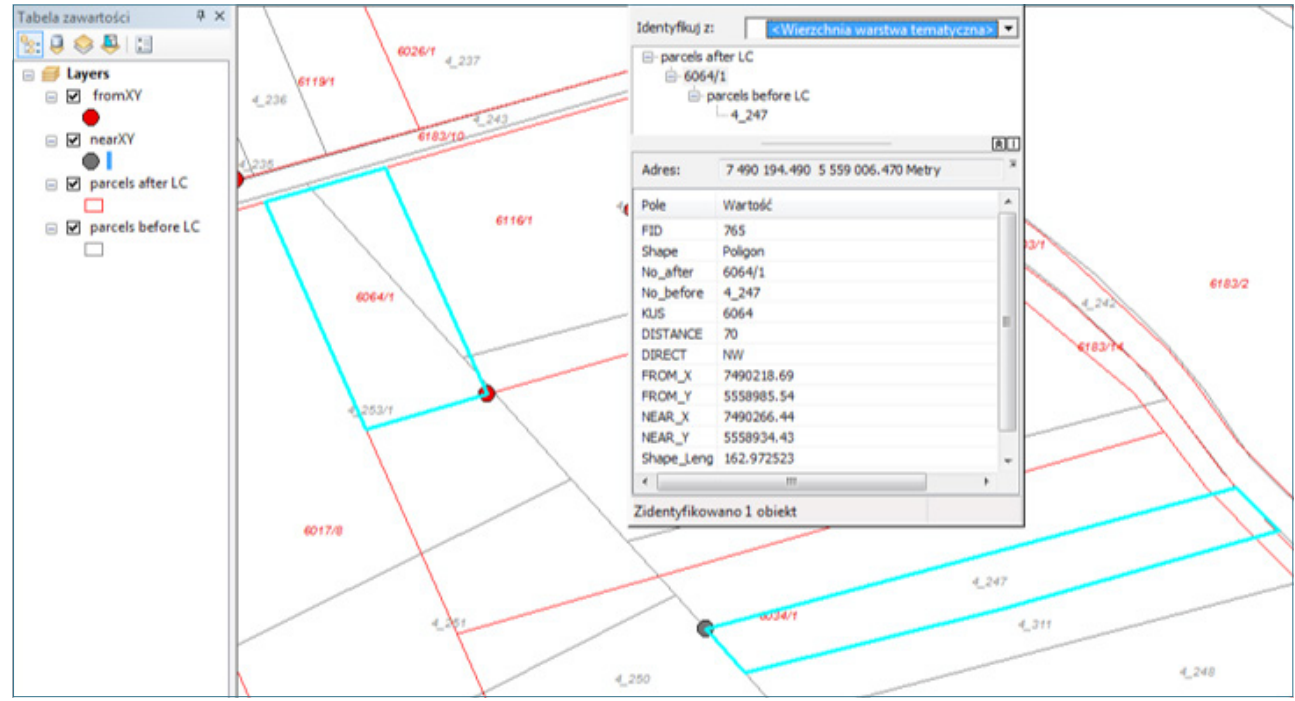

Fig. 6. Control of results 
There were 728 such cases, i.e. about $80 \%$ of all plots. In other cases, the results were correct in terms of computation, and the location of the nearest plot was also indicated correctly, but the descriptive information about the distance and direction could not be used directly in each case. It was used to describe the location of the new plot, but not in each case to point a meeting place on the ground. Participants are usually called in characteristic places, which are easily found and described, for example, on a specific street. Including roads in the majority of villages would not have much impact on GIS analyzes, as they are mostly access roads without names. A partial alternative could be a reference to characteristic objects such as churches and schools. But in addition, it must be correlated with the appointed time of the meeting, which is problematic.

As for the method of calculating the distance between plots, an alternative would be to calculate the distance between centroid plots, but this method seems to be much more inaccurate, especially in the case of irregular plots. Alternatively, a description of the path from the plot before consolidation into the plot after the consolidation can be generated using network analysis tools. However, the problem of identifying specific access roads also appears here.

\section{Conclusions}

Using the GIS system, a tool was developed to automatically obtain information about the number, direction and distance of objects nearest to the input objects and point on the map the nearest objects. This tool in the form of a model can be done in commercial software, for example, ARCGIS - ModelBuilder, as well as free software such as QGIS-Modeler.

The automation can be used in the preparation of calls for land consolidation participants, which provide information on the location of new plots in relation to the location of currently owned plots. The information about the nearest plot and the possibility of pointing it on the map is particularly useful and simplifies the work.

The tool's operation has been verified. The calculated values and the selection of the nearest plot are determined correctly. However, it was not possible to obtain full automation in the development of calls, because by calling the participants of the consolidation to the ground, a meeting place is appointed in a characteristic place, for example at a specific road and convenient place for both surveyors-designers and participants. Providing the distance and direction itself, especially at long distances, may not be very accurate. Nevertheless, the ability to automatically indicate the nearest plots before consolidation in relation to a newly designed plot is an extremely valuable and significantly accelerating work thing.

In the Nieciecza LC object, nearly $80 \%$ of plots of land after consolidation intersected with the nearest plots before consolidation, taking into account the same owner's plot (KUS). Therefore, in this case, automatically obtained results could be used directly in most cases. 


\section{References}

[1] Ustawa z dnia 26 marca 1982 r. o scalaniu i wymianie gruntów [Land consolidation and exchange act]. Dz.U. 2018 poz. 908.

[2] Basista I., Dębińska E.: The concept of geo-portal for land consolidation. [in:] SGEM2013: GeoConference on Informatics, geoinformatics and remote sensing: $13^{\text {th }}$ international multidisciplinary scientific geoconference: 16-22, June, 2013, Albena, Bulgaria: conference proceedings, vol. 1, STEF92 Technology Ltd., Sofia 2013, pp. 565-570.

[3] Basista I.: Geoportal na potrzeby procesu scalania i wymiany gruntów [Geoportal for the needs land consolidation process]. Roczniki Geomatyki = Annals of Geomatics / Polskie Towarzystwo Informacji Przestrzennej, vol. 11, 2013, pp. 7-12.

[4] Bożek P.: Determining the parameters of arable land fragmentation. Geodesy and Cartography, vol. 68(1), 2019, pp. 163-176.

[5] Balawejder M., Wójciak E.: Application of GIS tools in analysing a road network providing access to cadastral parcels in the project concerning land consolidation and exchange. [in:] Adamczyk T., Dębińska E. (eds.), "GIS ODYSSEY 2017": Geographic Information Systems Conference and Exhibition: $4^{\text {th }}$ to $8^{\text {th }}$ of September 2017, Trento - Vattaro, Italy: conference proceedings, Croatian Information Technology Society - GIS Forum, Zagreb 2017, pp. 13-21

[6] Bożek P., Janus J.: The influence of elevation data generalization on the accuracy of the RUSLE Model. [in:] 2017 Baltic Geodetic Congress (BGC Geomatics), IEEE, 2017, pp. 374-377.

[7] Basista I.: Przykłady wykorzystania narzędzi GIS w procesie scalania i wymiany gruntów [The use of GIS tools in the land consolidation and exchange process examples]. Infrastruktura i Ekologia Terenów Wiejskich = Infrastructure and Ecology of Rural Areas, no. IV/1, 2015, pp. 1047-1055.

\section{Wykorzystanie narzędzi GIS do opisu lokalizacji nowych działek ewidencyjnych}

Streszczenie: Artykuł prezentuje możliwość wykorzystania systemu informacji geograficznej GIS w zakresie opracowania wezwań dla uczestników scaleń gruntów. Pokazuje narzędzia oraz sposób ich wykorzystania, a także możliwość automatyzacji tego procesu.

W procesie scalenia i wymiany gruntów, po opracowaniu projektu scalenia, przygotowywuje się pisma dla uczestników scalenia, w których wzywa się ich do stawienia się $\mathrm{w}$ terenie, $\mathrm{w}$ celu okazania nowej lokalizacji działek. Pisma, zwykle opracowywane są ręcznie, a miejsca spotkań w nich przedstawione opisuje się odnosząc się do najbliższych działek stanu przed scaleniem. 
W zawiadomieniu podaje się między innymi informacje o tym, w jakiej odległości i jakim kierunku nowa działka jest oddalona od najbliższej do niej działki według poprzedniego stanu.

Wykorzystując system GIS, opracowano narzędzie pozwalające automatycznie uzyskać informacje o oznaczeniu, kierunku i odległości obiektów najbliższych do obiektów wejściowych oraz wskazać na mapie wybrane obiekty najbliższe. Otrzymane wyniki zostały skontrolowane, a wykorzystane narzędzia ocenione pod kątem przydatności do tego typu zadania.

Stwierdzono, że podanie samej odległości i kierunku, szczególnie w przypadku dużych odległościach, może być mało dokładne. Niemniej jednak możliwość automatycznego wskazania najbliższych działek przed scaleniem w stosunku do działki nowo zaprojektowanej jest niezwykle cennym i znacznie przyspieszającym pracę elementem. Dotyczy to zwłaszcza sytuacji, gdy w scaleniu gruntów bierze udział wielu właścicielach gruntów.

\section{Słowa}

kluczowe: wyszukiwanie obiektów najbliższych, scalenia gruntów, GIS 